\title{
PEMBINAAN MASYARAKAT QUR'ANI DI KECAMATAN MANGGALA MELALUI KKN STIBA MAKASSAR
}

\section{FOSTERING QUR'ANIC COMMUNITY IN MANGGALA DISTRICT THROUGH KKN STIBA MAKASSAR}

\author{
Rachmat bin Badani Tempo \\ Sekolah Tinggi Ilmu Islam dan Bahasa Arab (STIBA) Makassar \\ rachmatbadani@stiba.ac.id \\ Ahmad Syaripudin \\ Sekolah Tinggi Ilmu Islam dan Bahasa Arab (STIBA) Makassar \\ ahmadsyaripudin@stiba.ac.id

\section{Irsyad Rafi} \\ Sekolah Tinggi Ilmu Islam dan Bahasa Arab (STIBA) Makassar \\ irsyadrafi@stiba.ac.id
}

\begin{tabular}{|c|c|}
\hline Keywords : & $A B S T R A C T$ \\
\hline $\begin{array}{l}\text { Arabic Language, } \\
\text { Community Development, } \\
\text { Manggala, STIBA Makassar }\end{array}$ & $\begin{array}{l}\text { Manggala sub-district is one of } 14 \text { sub-districts in Makassar city. The } \\
\text { area of Manggala sub-district is } 24.14 \mathrm{~km}^{2} \text { or } 13.73 \% \text { of the area of } \\
\text { Makassar City. Manggala sub-district consists of } 8 \text { villages namely } \\
\text { Bontoala, Bangkala, Batua, Borong, Manggala, Tamangapa, Biring } \\
\text { Romang and Antang. The purpose of this STIBA Makassar Real } \\
\text { Work Lecture (KKN) batch IV is a form of community service which } \\
\text { is a pillar of the Tri Dharma of Higher Education. The method of } \\
\text { implementing community service programs begins with mapping the } \\
\text { problems and needs of the community using SOAR. After the analysis } \\
\text { is carried out, a work program is prepared that is appropriate and } \\
\text { needed by the community. Work programs that have been } \\
\text { successfully implemented include: socialization and friendship (SS), } \\
\text { TKA / TPA management training, TKA / TPA teaching, teaching of } \\
\text { the Qur'anic tahfidz, National Seminar on Virtual Arabic (SNBAV), } \\
\text { Subuh Reaching Blessings (SMK), Tahfidz Weekends (TW), Learning } \\
\text { Yajwid and Halaqah Tahsin, and all of these programs have been } \\
\text { running well and have shown initial results in accordance with the } \\
\text { stated objectives of the Community Service Program. }\end{array}$ \\
\hline Kata kunci : & ABSTRAK \\
\hline $\begin{array}{l}\text { Bahasa Arab, Pembinaan } \\
\text { Masyarakat, Manggala, STIBA } \\
\text { Makassar }\end{array}$ & $\begin{array}{l}\text { Kecamatan Manggala adalah salah satu dari } 14 \text { kecamatan yang } \\
\text { berada di Kota Makassar. Luas wilayah Kecamatan Manggala adalah } \\
24,14 \mathrm{~km}^{2} \text { atau } 13,73 \% \text { dari luas Kota Makassar. Kecamatan } \\
\text { Manggala terdiri dari } 8 \text { kelurahan yaitu Bontoala, Bangkala, Batua, } \\
\text { Borong, Manggala, Tamangapa, Biring romang dan Antang. Tujuan } \\
\text { dari Kuliah Kerja Nyata (KKN) STIBA Makassar angkatan IV ini } \\
\text { adalah sebagai wujud pengabdian kepada masyarakat yang } \\
\text { merupakan pilar dari tri dharma perguruan tinggi. Metode }\end{array}$ \\
\hline
\end{tabular}


Website: https://journal.stiba.ac.id ISSN: 2723-6013 (Online)

\begin{abstract}
pelaksanaan program pengabdian dimulai dengan melakukan pemetaan masalah dan kebutuhan masyarakat menggunakan SOAR Analysis. Setelah analisis dilakukan, maka disusun program kerja yang sesuai dan dibutuhkan oleh masyarakat. Program kerja yang berhasil dilaksanakan di antaranya adalah: sosialisasi dan silaturahim (SS), pelatihan manajemen TKA/TPA, pengajaran TKA/TPA, pengajaran tahfidz Al-Qur'an, Seminar Nasional Bahasa Arab Virtual (SNBAV), Subuh Menggapai Keberkahan (SMK), Tahfidz Weekend (TW), pembelajaran tajwid dan halaqah tahsin, dan semua program ini berhasil berjalan dengan baik dan telah menampakkan hasil awal sesuai dengan tujuan KKN yang telah dicanangkan.
\end{abstract}

Diterima: 27 April 2021; Direvisi: 12 Mei 2021; Disetujui: 22 Mei 2021; Tersedia online: 18 Juni 2021

How to cite: Rachmat bin Badani Tempo, Ahmad Syaripuddin, Irsyad Rafi. "Pembinaan Masyarakat Qur'ani di Kecamatan Manggala Melalui KKN STIBA Makassar”, WAHATUL MUJTAMA': Jurnal Pengabdian Masyarakat Vol.2, No.1 (Juni 18, 2021): 21-30. doi: https://doi.org/10.36701/wahatul.v2i1.340

\title{
PENDAHULUAN
}

Kecamatan Manggala adalah salah satu dari 14 kecamatan yang berada di Kota Makassar. Luas wilayah Kecamatan Manggala adalah 24,14 km² atau 13,73\% dari luas Kota Makassar. Kecamatan Manggala terdiri dari 8 kelurahan yaitu Bontoala, Bangkala, Batua, Borong, Manggala, Tamangapa, Biring Romang dan Antang, dan semuanya sudah berstatus swasembada ${ }^{1}$.

Letak Geografis Kecamatan Manggala adalah 5,1752 derajat Lintang Selatan, 119,4935 derajat Lintang Barat Timur. Dengan jumlah penduduk sebesar 149.487 pada tahun 2019. Adapun batas wilayah Kecamatan Manggala adalah dari sebelah utara berbatasan dengan Kecamatan Tamalanrea; sebelah selatan berbatasan dengan Kabupaten Gowa; sebelah timur berbatasan dengan Kabupaten Maros; dan sebelah barat berbatasan dengan Kecamatan Panakukang. Adapun jika dilihat dari ketinggian masing-masing kelurahan dari permukaan laut, maka Kelurahan Antang yang paling tinggi yaitu 24 meter di atas permukaan laut sedangkan yang terendah adalah Kelurahan Borong dan Kelurahan Bangkala yang memiliki ketinggian kurang lebih 7 meter dari permukaan laut ${ }^{2}$.

Berdasarkan uraian singkat berkenaan profil Kecamatan Manggala di atas, maka pelaksanaan program kerja KKN STIBA Makassar angkatan IV dinilai dapat memberikan kontribusi bagi pengembangan kualitas SDM masyarakat di wilayah

${ }^{1}$ Syamsuddin, Kecamatan Manggala Dalam Angka 2020, ed. Seksi IPDS (Makassar: BPS kota Makassar, n.d.). h. 4.

2 Kecamatanmanggala.Com," n.d., http://kecamatanmanggala.com/profil-kecamatan/. Diakses 22 Mei 2021 
tersebut. Untuk itu, ditetapkan tujuan pelaksanaan KKN yaitu: (1) Untuk mengambil peran dalam membantu pemerintah Kecamatan Manggala dalam mewujudkan misi pembinaan mental dan spritual antar umat beragama ${ }^{3}$; (2) Untuk meningkatkan kesadaran sosial dan dakwah mahasiswa STIBA Makassar dalam berkontribusi pada peningkatan SDM masyarakat di Kecamatan Manggala; (3) STIBA Makassar sebagai perguruan tinggi keagamaan Islam berkewajiban dalam melaksanakan tri dharma perguruan tinggi pada pilar pengabdian masyarakat.

Sebelum menetapkan program kerja KKN di Kecamatan Manggala, di mana pihak STIBA Makassar bekerja sama dengan Dewan Pimpinan Daerah Wahdah Islamiyah Kota Makassar dalam mendukung program Pemerintah Kota Makassar, terlebih dahulu dilakukan survei lapangan untuk keperluan analisis kebutuhan program pemberdayaan masyarakat, dengan mengaplikasikan instrumen sederhana yang kemudian dilakukan analisis SOAR secara ringkas sebagai berikut:

1. Strength, keadaan secara umum masyarakat yang religius dan masih mempertahankan tradisi yang baik. Adanya taman pendidikan Al-Qur'an di setiap kelurahan. Jumlah penduduk usia produktif yang banyak. Selain itu, mahasiswa KKN telah dibekali dengan pelatihan yang menunjang pelaksanaan kegiatan keagamaan di masyarakat.

2. Oppurtunities, adanya dukungan dari Dewan Pimpinan Pusat Wahdah Islamiyah yang berkedudukan di Kecamatan Manggala dan dukungan DPD Wahdah Islamiyah Kota Makassar dalam melaksananakan program kerja. Dukungan pemerintah setempat beserta akses transportasi dan informasi yang mudah

3. Aspiration, pengetahuan tentang keutamaan belajar bahasa Arab yang masih minim, khususnya usia remaja. Masih minimnya skills dan pengetahuan manajerial yang baik dalam mengelola dan membina TK/TPA di wilayah Kecamatan Manggala. Kegiatan keagamaan yang masih perlu ditingkatkan kualitasnya di wilayah Kecamatan Manggala. Kurangnya tenaga pengajar TK/TPA para santri di beberapa tempat. Kebutuhan akan tenaga pengajar AlQur'an untuk pemantapan bacaan dengan tajwid yang benar untuk kalangan orang tua dan remaja.

4. Result, terwujudnya masyarakat yang mengamalkan Islam secara baik, terwujudnya generasi muda yang dekat dengan nilai Islam dan memiliki perhatian terhadap kondisi umat. Terwujudnya generasi qurani dengan berdirinya TPA di setiap masjid.

Dengan memperhatikan analisis SOAR di atas, kemudian ditetapkan beberapa program kerja KKN STIBA Makassar angkatan IV di Kecamatan Manggala sebagai berikut, sosialisasi dan silaturahim (SS), Pelatihan Manajemen

\section{${ }^{3}$ Ibid.}


TK/TPA, pengajaran TK/TPA, pengajaran Tahfidz, Seminar Nasional Bahasa Arab Virtual (SNBAV), Subuh Menggapai Keberkahan (SMK), Pelatihan Multimedia (PM), Tahfidz Weekend (TW), Pembelajaran Tajwid dan Halaqah Tahsin.

Pelaksanaan program KKN pengabdian dengan pendekatan Al-Qur'an telah dilakukan sebelumnya oleh mahasiswa KKN STIBA Makassar di beberapa daerah sebagai berikut:

1. Pengabdian yang dilakukan di Desa Kalabbirang Kecamatan Bantimurung, Kabupaten Maros Sulawesi Selatan dengan tema mewujudkan masyarakat qurani di mana program yang dilaksanakan bertujuan untuk mendekatkan masyarakat kepada Al-Qur'an baik secara bacaan maupun pengamalan. Semua program berjalan dengan baik, terlihat dengan adanya peningkatan kualitas bacaan Al-Qur'an masyarakat yang mengikuti program $\mathrm{KKN}$ ini ${ }^{4}$.

2. Pengabdian mahasiswi KKN STIBA di Desa Tukamase Kecamatan Bantimurung. Dengan mengusung program dirosah quraniah yaitu serangkaian kegiatan pengajaran Al-Qur'an dan taklim keislaman serta bahasa Arab juga program wakaf Al-Qur'an. Kegiatan ini mendapat dukungan dari masyarakat dan pemerintah setempat karena membantu mengatasi buta aksara Al-Qur'an pada masyarakat yang juga merupakan program pemerintah daerah setempat. Pasca program dilaksanakan terlihat perbaikan bacaan Al-Qur'an yang semakin baik dan pemahaman masyarakat yang lebih dekat pada AlQur'an ${ }^{5}$.

Melihat program pengabdian yang telah dilaksanakan tersebut di beberapa tempat di wilayah Sulawesi Selatan khususnya di Kabupaten Maros, maka KKN STIBA angkatan IV ini difokuskan ke wilayah Kecamatan Manggala Kota Makassar untuk meningkatkan kualitas pengajaran Al-Qur'an dan pembinaan masyarakat Islami.

\section{PEMBAHASAN}

\section{Sosialisasi dan Silaturahmi (SS)}

Program ini bertujuan untuk memperkenalkan tim mahasiswa KKN angkatan IV STIBA Makassar, menyosialisasikan rencana program kerja, mengkoordinasikan beberapa kegiatan yang membutuhan kerjasama antar

${ }^{4}$ Sartini La Mbadjo and Ahmad Hanafi, "Mewujudkan Masyarakat Qurani Di Desa Kalabbirang Melalui Program KKN Stiba Makassar," Wahatul Mujtama' Jurnal Pengabdian Masyarakat Sekolah Tinggi ILmu Islam Dan Bahasa Arab (STIBA) 1, no. 2 (2020): 157-73, doi:https://doi.org/10.36701/wahatul.v1i2.255.

${ }^{5}$ Iskandar Iskandar and M Amirullah, "Pelaksanaan Dirasah Quraniyah Sebagai Upaya Peningkatan Kualitas Baca Alquran Di Desa Tukamase," Wahatul Mujtama' Jurnal Pengabdian Masyarakat Sekolah Tinggi ILmu Islam Dan Bahasa Arab (STIBA) 1, no. 1 (2020): 42-53, doi:https://doi.org/10.36701/wahatul.v1i1.135. 
mahasiswa dan Dewan Pimpinan Daerah (DPD) WI Makassar dan mempererat jalinan silaturahmi dengan pengurus DPD Wahdah Islamiyah kota Makassar. Selain itu, manfaat melakukan silaturahmi sebelum melaksanakan KKN ialah untuk menumbuhkan karakter mahasiswa ${ }^{6}$.

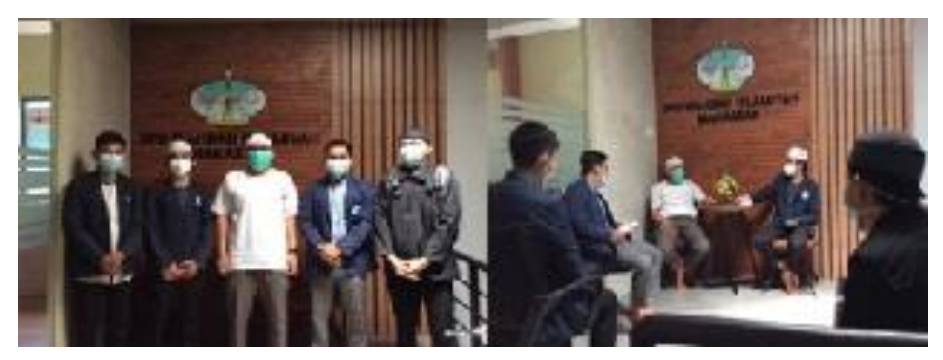

Gambar 1. Silaturahim ke DPD WI Kota Makassar

Hasil dari kegiatan ini adalah adanya dukungan penuh dari DPD WI Makassar dan beberapa program dapat disinergikan dengan program kerja DPD yang sedang berjalan.

\section{Seminar Nasional Bahasa Arab Virtual}

Kegiatan ini dilaksanakan via Zoom dan Youtube STIBA TV dan bekerjasama dengan Himpunan Pelajar Muslim Indonesia (HILMI) dan panitia penerimaan mahasiswa baru (PMB) STIBA Makassar 2021. Kegiatan ini bermuatan materi tentang keutamaan bahasa Arab dan dirangkaikan dengan sosialisasi PMB STIBA Makassar. Kegiatan ini diikuti sekitar 250 peserta dari kalangan pelajar SMP dan SMA di seluruh Indonesia.

Hasil dari kegiatan ini adalah penambahan wawasan peserta tentang keutamaan mempelajari bahasa Arab sekaligus mengenal kampus STIBA Makassar sebagai salah satu perguruan tinggi di Indonesia yang mengajarkan dan menggunakan bahasa Arab sebagai bahasa pengantar perkuliahan. Sehubungan dengannya, Munawara dan Iskandar menyebutkan bahwa dalam proses pengajaran bahasa Arab perlu dibarengi dengan pengajaran makharijul huruf ${ }^{7}$. Adapun tindak lanjut dari kegiatan ini adalah, penawaran kegiatan serupa di grup Whatsapp peserta seminar, serta bekerja sama dengan HILMI selaku salah satu organisasi yang memberikan perhatian pada pembinaan pelajar muslim di Indonesia.

\footnotetext{
${ }^{6}$ Aqbar, Khaerul, and Putra Alam. "Stimulasi Dakwah Menuju Masyarakat Qur'ani melalui KKN STIBA Makassar di Desa Alatengae Kabupaten Maros." WAHATUL MUJTAMA': Jurnal Pengabdian Masyarakat 1.2 (2020): 209-221.

7 Munawara, Munawara, and Iskandar Iskandar. "Implementasi Pengabdian Masyarakat melalui Pelaksanaan Dirasah Islamiyah di Desa Tukamasea Kabupaten Maros." WAHATUL MUJTAMA': Jurnal Pengabdian Masyarakat 1.2 (2020): 174-184.
} 

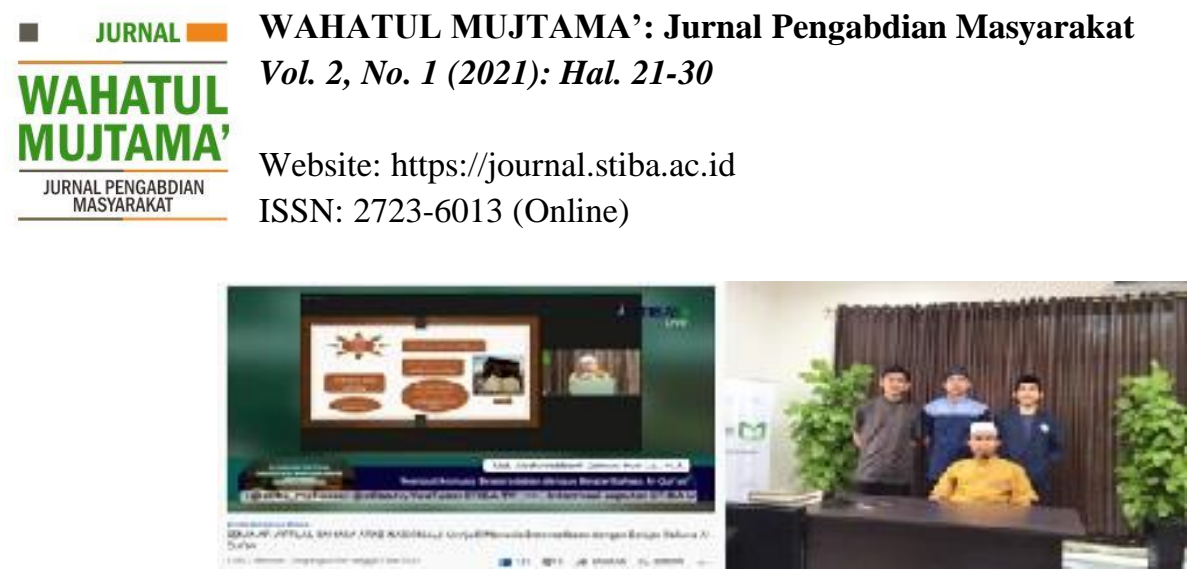

Gambar 2. Seminar Nasional Bahasa Arab Virtual

\section{Pelatihan Manajemen TKA/TPA}

Kegiatan ini difokuskan bagi praktisi dan pengelola TKA/TPA yang berada di Kecamatan Manggala dan Kota Makassar. Kegiatan ini dilaksanakan secara daring via Zoom meeting bekerjasama dengan departemen kaderisasi Dewan Eksekutif Mahasiswa (DEMA) STIBA Makassar. Dalam kegiatan ini disajikan materi pengajaran dan manajemen TK/TPA.
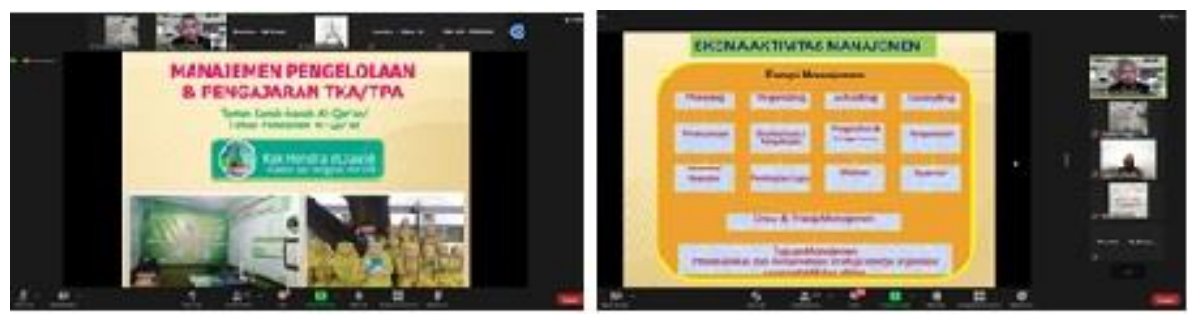

Gambar 3. Pelatihan Manajemen TKA/TPA

Adapun menurut Farida, dkk, mengatakan bahwa pelatihan manajemen TPA itu sangat penting dikarenakan keberadaan TPA berimplikasi pada: 1) menciptakan generasi Islam yang taat beribadah dan berakhlak mulia; 2) memakmurkan masjid; 3) menanankan nilai-nilai budi pekerti yang baik dengan meneladani Rasulullah saw. dan para sahabatnya; 4) membentuk masyarakat yang Qurani; 5) menanamkan nilai moral dan budi pekerti pada generasi muda; 6) memperdalam pengetahuan keagamaan di masyarakat; 7) membantu pemerintah dalam mengembangkan pendidikan berbasis masyarakat ${ }^{8}$. Dengan demikian, tampak pula hasil dari kegiatan ini yaitu bertambahnya wawasan peserta tentang materi ajar, metode pengajaran dan cara pengelolaan TK/TPA yang baik, sehingga dapat berimplikasi positif pada santri-santriwasi.

${ }^{8}$ Farida, Siti, Munib Munib, and Badrut Tamam. "PELATIHAN MANAJEMEN DALAM PENINGKATAN KUALITAS PENGELOLAAN TAMAN PENDIDIKAN AL-QUR'AN (TPA) NURUL HIDAYAH SAMPANG." AL-KHIDMAH: Jurnal Pengabdian Kepada Masyarakat 1.1 (2020): 34-46. 
Website: https://journal.stiba.ac.id ISSN: 2723-6013 (Online)

\section{Subuh Menggapai Berkah (SMK)}

Kegiatan ini diperuntukan bagi internal remaja masjid dan pengurus TKA/TPA Nurul Badar yang dilaksanakan di Masjid Nurul Badar, Kelurahan Ujung Bori. Kegiatan ini berisi rangkaian kegiatan Workshop Desain Video dengen menggunakan aplikasi Kine Master, mabit (bermalam bersama dengan tujuan untuk mengamalkan sunah di malam hari seperti muhasabah sebelum tidur, zikir sebelum tidur, dan salat malam), tilawah Al-Qur'an dan olahraga. Secara khusus, menurut Rachmat dan Khaerul menyatakan bahwa tujuan dari mabit adalah ajang untuk memberikan arahan dan motivasi kepada para remaja agar dapat menjadi pemuda pembawa perubahan (agent of change) ${ }^{9}$.

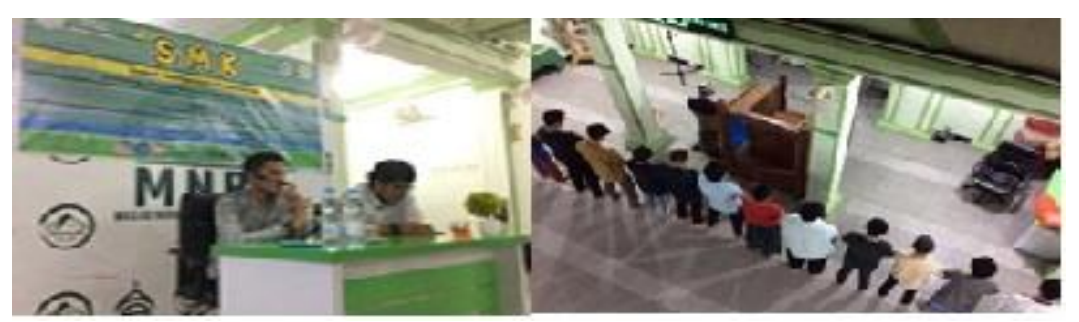

Gambar 4. Kegiatan Subuh Menggapai Berkah

Hasil dari kegiatan ini adalah bertambahnya wawasan keislaman dan pengamalan sunah serta kemampuan penggunaan aplikasi Kine Master bagi anak remaja di sekitar wilayah kelurahan Antang, khususnya remaja sekitar masjid Nurul Badar Ujung Bori. Adapun follow up dari kegiatan ini akan dilanjutkan oleh DPD WI Makassar dalam bentuk kerjasama dengan remaja masjid dalam melaksanakan kegiatan selanjutnya.

\section{Pengajaran TKA/TPA}

Kegiatan ini dilaksanakan di dua Taman Pengajian Al-Qur'an yaitu Masjid Bin Baz dan Masjid Jabal Hiroh. Waktu pelaksanaan dilakukan pada hari seninJumat dan dimulai pada jam 14.00-16.00 WITA dan setelah magrib sampai isya. kegiatan ini akan tetap dilanjutkan setelah berakhirnya masa KKN dengan menempatkan peserta KKN di masjid tersebut. Pada dasarnya Eka dan Awal menyebutkan bahwa pengajaran TKA/TPA merupakan sebuah kegiatan keagamaan yang berfungsi sebagai media untuk memperkenalkan kepada anak usia dini tentang cara membaca Al-Qur'an dengan baik dan benar ${ }^{10}$.

9 Tempo, Rachmat Bin Badani, and Khaerul Aqbar. "Ikhtiar Mahasiswa KKN STIBA Makassar dalam Pembentukan Akhlak Qur'ani Masyarakat Desa Balassuka Kabupaten Gowa." WAHATUL MUJTAMA': Jurnal Pengabdian Masyarakat 1.1 (2020): 90-115.

10 Syahriani, Eka, and Awal Rifai. "Upaya Meningkatkan Pemahaman Keagamaan Masyarakat melalui Program Pendidikan dan Sosial Keagamaan di Desa Alatengae Kabupaten Maros." WAHATUL MUJTAMA': Jurnal Pengabdian Masyarakat 1.2 (2020): 142-156. 

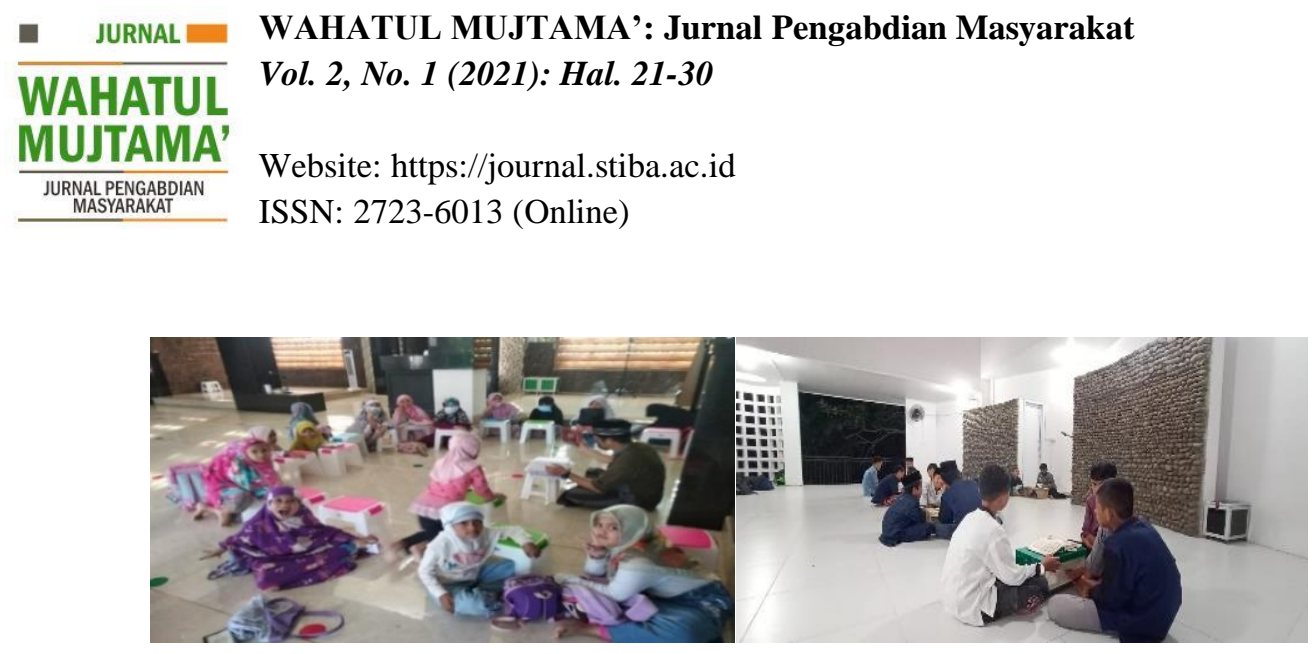

Gambar 5. Kegiatan Pengajaran TKA/TPA

\section{Tahfidz, Weekend}

Tahfidz Weekend adalah kegiatan menghafal Al-Qur'an yang diselenggarakan di akhir pekan dan dilaksanakan di Masjid Jabal Hiroh. Kegiatan ini dilakukan sejak sabtu sore dan berakhir pada ahad pagi. Muatan program ini antara lain penyetoran hafalan Al-Qur'an, materi tajwid, olahraga dan breafing. Adapun Rachmat dan Khaerul mengatakan bahwa di antara manfaat dari kegiatan menghafal Al-Qur'an adalah sebagai sarana penyetoran hafalan sekaligus perbaikan bacaan santri, dan tentunya menambah jumlah setoran hafalan santri dan memperbaiki bacaan atau hafalan yang keliru ${ }^{11}$.

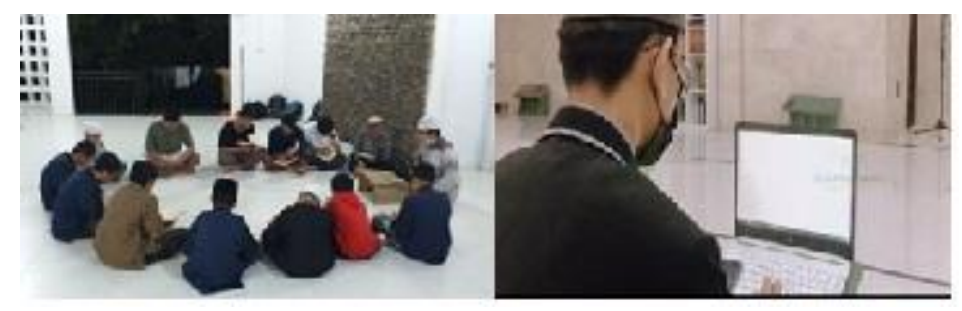

Gambar 6. Kegiatan Tahfidz Weekend

Sehubungan dengan itu pula, hasil dari kegiatan ini adalah bertambahnya hafalan Al-Qur'an para peserta, kegiatan ini akan tetap dilanjutkan setelah berakhirnya masa KKN dengan menempatkan peserta KKN di masjid ini.

\section{Pengajaran Tahsin dan Pengajaraan Ilmu Tajwid}

Kegiatan pengajaran tahsin dilaksanakan setiap malam ahad untuk masyarakat sekitar bukit baruga I dan dilaksanakan juga via Zoom meet atau Google meet untuk para pengurus dan guru yayasan amal jariah setiap senin sore, selasa dan rabu malam. Adapun pelaksanaan tahsin umumnya diajarkan kepada ibuibu, bapak-bapak dan/atau remaja yang kemampuan membaca Al-Qur'an-nya

11 Tempo, Rachmat Bin Badani, and Khaerul Aqbar. "Ikhtiar Mahasiswa KKN STIBA Makassar dalam Pembentukan Akhlak Qur'ani Masyarakat Desa Balassuka Kabupaten Gowa." WAHATUL MUJTAMA': Jurnal Pengabdian Masyarakat 1.1 (2020): 90-115. 
sudah cukup memadai ${ }^{12}$. Adapun kegiatan pengajaran ilmu tajwid dilaksanakan pada setiap subuh pada hari senin, rabu dan Jumat. Kegiatan ini diperuntukkan bagi anak-anak santri sekitar daerah Bukit Baruga 1, dan juga secara khusus Pondok ArRahman Quran Learning (AQL).

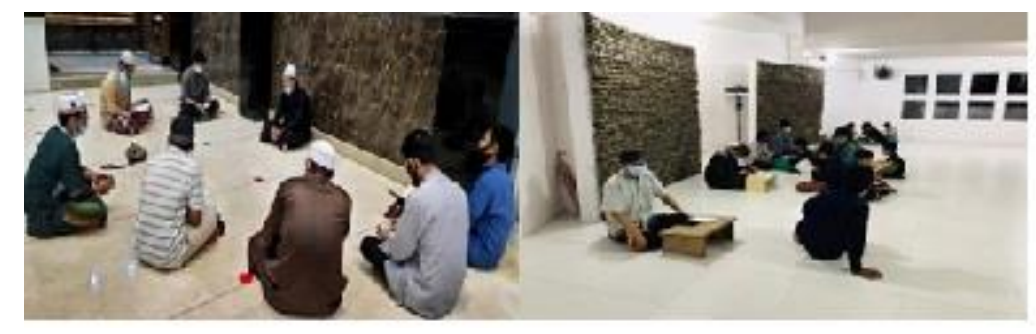

Gambar 7. Kegiatan Pengajaran Tahsin \& Ilmu Tajwid

Hasil dari kedua kegiatan ini adalah adanya peningkatan kemampuan peserta dalam membaca Al-Qur'an dengan menerapkan kaidah tajwid, kegiatan ini akan tetap dilanjutkan setelah berakhirnya masa KKN dengan menempatkan peserta KKN di masjid ini.

\section{KESIMPULAN}

Kuliah Kerja Nyata (KKN) STIBA Makassar angkatan IV ini adalah sebagai wujud pengabdian kepada masyarakat yang merupakan pilar dari tri dharma perguruan tinggi. Program kerja yang dilaksanakan oleh mahasiswa KKN STIBA Makassar angkatan IV di Kecamatan Manggala di antaranya adalah: sosialisasi dan silaturahim (SS), pelatihan manajemen TK/TPA, pengajaran TK/TPA, pengajaran Tahfidz , Seminar Nasional Bahasa Arab Virtual (SNBAV), Subuh Menggapai Keberkahan (SMK), Tahfidz. Weekend (TW), pembelajaran tajwid dan halaqoh tahsin. Semua program tersebut telah menampakkan hasil awal yang cukup signifikan sesuai dengan tujuan KKN yang telah dicanangkan namun masih membutuhkan tindak lanjut untuk hasil yang lebih maksimal.

\section{DAFTAR PUSTAKA}

Aqbar, Khaerul, and Putra Alam. "Stimulasi Dakwah Menuju Masyarakat Qur'ani melalui KKN STIBA Makassar di Desa Alatengae Kabupaten Maros." WAHATUL MUJTAMA': Jurnal Pengabdian Masyarakat 1.2 (2020): 209221.

Farida, Siti, Munib Munib, and Badrut Tamam. "PELATIHAN MANAJEMEN DALAM PENINGKATAN KUALITAS PENGELOLAAN TAMAN PENDIDIKAN AL-QUR'AN (TPA) NURUL HIDAYAH SAMPANG." AL-

${ }^{12}$ Patahuddin, Askar, and Jujuri Perdamaian Dunia. "Menyiapkan SDM Unggul dan Religius melalui Ikhtiar Kegiatan Keagamaan di Desa Jonjo Kabupaten Gowa." WAHATUL MUJTAMA': Jurnal Pengabdian Masyarakat 1.2 (2020): 116-128. 
KHIDMAH: Jurnal Pengabdian Kepada Masyarakat 1.1 (2020): 34-46.

Iskandar, Iskandar, and M Amirullah. "Pelaksanaan Dirasah Quraniyah Sebagai Upaya Peningkatan Kualitas Baca Alquran Di Desa Tukamase." Wahatul Mujtama' Jurnal Pengabdian Masyarakat Sekolah Tinggi ILmu Islam Dan Bahasa Arab (STIBA) 1, no. 1 (2020): 42-53. doi:https://doi.org/10.36701/wahatul.v1i1.135.

"Kecamatanmanggala.Com," n.d.

Mbadjo, Sartini La, and Ahmad Hanafi. "Mewujudkan Masyarakat Qurani Di Desa Kalabbirang Melalui Program KKN Stiba Makassar." Wahatul Mujtama' Jurnal Pengabdian Masyarakat Sekolah Tinggi ILmu Islam Dan Bahasa Arab $\begin{array}{lllll}(S T I B A) & 1, & \text { no. } & 2 & \text { (2020): }\end{array}$ doi:https://doi.org/10.36701/wahatul.v1i2.255.

Munawara, Munawara, and Iskandar Iskandar. "Implementasi Pengabdian Masyarakat melalui Pelaksanaan Dirasah Islamiyah di Desa Tukamasea Kabupaten Maros." WAHATUL MUJTAMA': Jurnal Pengabdian Masyarakat 1.2 (2020): 174-184.

Patahuddin, Askar, and Jujuri Perdamaian Dunia. "Menyiapkan SDM Unggul dan Religius melalui Ikhtiar Kegiatan Keagamaan di Desa Jonjo Kabupaten Gowa." WAHATUL MUJTAMA': Jurnal Pengabdian Masyarakat 1.2 (2020): 116-128.

Syamsuddin. Kecamatan Manggala Dalam Angka 2020. Edited by Seksi IPDS. Makassar: BPS kota Makassar, n.d.

Syahriani, Eka, and Awal Rifai. "Upaya Meningkatkan Pemahaman Keagamaan Masyarakat melalui Program Pendidikan dan Sosial Keagamaan di Desa Alatengae Kabupaten Maros." WAHATUL MUJTAMA': Jurnal Pengabdian Masyarakat 1.2 (2020): 142-156.

Tempo, Rachmat Bin Badani, and Khaerul Aqbar. "Ikhtiar Mahasiswa KKN STIBA Makassar dalam Pembentukan Akhlak Qur'ani Masyarakat Desa Balassuka Kabupaten Gowa." WAHATUL MUJTAMA': Jurnal Pengabdian Masyarakat 1.1 (2020): 90-115. 